\title{
Additional Posers in the Provocation Law of Nigeria
}

\author{
By G. N. Vukor-Quarshie
}

\section{Introduction}

In an earlier article on provocation and the criminal law of Nigeria ${ }^{1}$ I examined the provisions of Sections 318, 283, 284 and 252 of the Criminal Code of Nigeria $^{2}$ and came to the conclusion that the provocation law of Nigeria is greatly different from English law on the subject. In that article I attempted to explain the provocation rules as contained in our Criminal Code; I also endeavoured to point out the extent to which Nigerian law differs from English law on this subject.

The present article attempts to foreshadow and provide answers to some additional posers that are likely to plague the criminal law of Nigeria when Section 318 of the Code is called into play. ${ }^{3}$

One of the greatest challenges facing many postindependent African nations is how to integrate the laws received from the departed colonialists with their local value systems. One area in which the criminal law of Nigeria needs to be integrated with Nigerian cultural as well as religious and social values is the uncompromising policy attitudes displayed towards the supernatural as a defence to criminal liability. ${ }^{4}$ The policy of the criminal law towards defendants who plead belief in supernatural phenomena like witchcraft, juju, or fetish-possession has been that such belief does not absolve from criminal

1 Are the heat of passion provisions of the Criminal Code of Nigeria as Defective as the critics maintain?" (To be published in Vol II/1987 of Ife Law Journal).

2 The Provocation rules under the Penal Code which are contained in S. 222 (1) are not expressly considered in these two articles. For a recent article which touches on some of the issues under the two Codes, see Dr. Chukkol's "The Reasonable man: Does he rexist under the Penal Code?" $(1984+1985$ Vols. $2+3$ A.B.U.L.J. p. 44).

3 S. 318 is the pivotal section dealing with cases in which a person kills as a result of provocation. It says that "when a person ... unlawfully kills another ... in the heat of passion caused by sudden provocation, and before there is time for his passion to cool, he is guilty of manslaughter only". It must be pointed out that Sections 252, 283 and 284 which are usually read alongside S. 318 in considering the defence of provocation under Nigerian law, respectively deal with assault, (S. 252) the definition of the term "provocation" (S. 283) and provocation as a defence to a charge of assault (S. 284).

4 For an illuminating and critical discussion of the subject, see Seidman: "Witch murder and mens rea: A Problem of Society under Radical Social Change", 28 M.L.R. 46. See also Aremu: "Criminal Responsibility for Homicide in Nigeria and Supernatural Beliefs", (1980) 29 I.C.L.Q. 112. 
responsibility. Typical of the judicial attitude is the judgement of the former West African Court of Appeal (W.A.C.A.) in Gadam, ${ }^{5}$ a case in which the reasonableness vel non of the defence of mistake raised by the accused to a charge of murder, had to be determined. The pertinent facts of this case are that the accused had killed an old woman whom he genuinely believed had employed witchcraft to cause the miscarriage and subsequent death of his wife. Although it was established in evidence that the accused person came from a community in which belief in witchcraft was widely held, the W.A.C.A. typically upheld the conviction for murder on the main ground that such belief was unreasonable. ${ }^{6}$ The W.A.C.A. then went on to justify this holding in the following terms:

"It would . . . be a dangerous precedent to recognize that because a superstition, which may lead to such a terrible result as is disclosed by the facts of this case, is generally prevalent among a community, it is therefore reasonable. The Courts must ... regard the holding of such beliefs unreasonable «?

It is obvious that the W.A.C.A. was greatly influenced by considerations of social defence in holding that belief in witchcraft would not exculpate from crime. Belief in the supernatural is so widespread in Nigeria that if the courts are to accept it as a ground for exculpation from criminal liability, social security will be tremendously underminded. ${ }^{8}$ What should be the attitude of our courts when faced with cases in which an actor, who is labouring under acute fear of juju or witchcraft kills? Should the defence of provocation be available to a person who kills another in the heat of passion caused by threats that juju or witchcraft would be invoked to cause him serious harm?

In Galikuwa v. R. ${ }^{9}$ the East African Court of Appeal had to deal with a case in which the appellant based his plea of provocation on the fact that the deceased, a witchdoctor, had threatened him with death unless he paid to him Shs. 1000/-. The appellant, being unable to pay the sum, killed the witchdoctor in the honest belief that that was the only way to save his life. The court convicted him of murder because there was no immediate provocative act. The court went on to observe that "a mere threat to cause injury to health or even death in the near future cannot be considered as physical provocative act". One of the major stumbling blocks in the path of successfully interposing a provocation plea where threats from juju or other supernatural forces are made is that, the normal

(1954) 14 W.A.C.A. 442.

6 S. 25 of the Nigerian Criminal Code which deals with the defence of mistake of fact requires, inter alia, that such mistake must be honest as well as reasonable.

7 The W.A.C.A. lifted the quoted passage from the trial judge in an earlier case, Ifereonwe v. R. (unreported).

8 In many villages in Nigeria, when illness or misfortune strikes a family, the practice is to pay fetish priests or priestesses or jujumen to consult "the dead" who will give reasons for such illness or misfortune. Invariably, someone in the village, usually very old men or women, who are either members of the family or neighbours are implicated in the affair. It is a common belief in the villages that very old women are witches who nourish themselves on the blood of young men and women.

9 (1951) 18 E.A.C.A. 175. 
emotion in this type of cases is "fear" and not anger, and the provocation cases seem to stress the requirement that the actor must have killed in the heat of anger caused by sudden provocation and not out of fear, and that if fear is the emotion involved, the proper defence to call into aid is self-defence. In Galikuwa, ${ }^{10}$ the East African Court of Appeal specifically said that in applying the defence of provocation in the witchcraft cases, the act causing death must be done in anger and that fear of immediate death is not enough. Prof. Ashworth, who is not normally given to making statements without carefully weighing the same says that "a loss of self-control caused by fear, panic or mental instability cannot be brought within defence of provocation ". ${ }^{11}$ It is submitted that nothing in Sections 318 or 283 of the Nigerian Criminal Code prevents the Nigerian courts from accepting a plea of provocation based on fear induced by threats from juju, witchcraft on other supernatural sources. S. 318 requires that the killing be done "in the heat of passion ..." It will be highly arbitrary and unrealistic to restrict the meaning of "passion" to the emotion of anger alone.

One of the important contributions of the widely criticised Cannon-Bard theory of emotional behaviour ${ }^{12}$ is that the physiology of fear is similar to that of anger. Fear as well as anger presents the subject with a flee-or-fight option. Valzelli reports that although "little has been systematically reported ... fear may presumably also act in man, by causing him to react violently when physically or psychologically confined, to stop his ongoing behaviour, or take flight, based upon environmental circumstances, previous experience..." ${ }^{13}$ Fear can be as psychologically overpowering as anger and does affect the choice and volitional capacities of the actor. People have been overpowered and have fainted under the sheer force of fear alone.

Let us re-examine the facts of one of the leading cases on the type of phenomenon under discussion. In Nwaoke, ${ }^{14} \mathrm{~N}$. pointed a powerful juju ${ }^{15}$ at the deceased who owed him money and said something to the effect:

"Since you refuse to pay me my money this juju will kill you; [or] since you refuse to pay me you shall no more eat or drink."

Now let us alter the facts of this case ${ }^{16}$ and assume that the party at whom he pointed the juju being very frightened, seized an axe and decapitated N. Should the defence of

1018 opp. cit.

11 "The Doctrine of Provocation" [1976] C.L.J. 292 at 297. It is unfortunate that Ashworth treats fear, panic and mental instability alike; G. Williams (op.cit., note 3, t p. 524) who notes that whilst fear is the dominant emotion in the law of self-defence, it is also capable of amounting to provocation.

12 See Brett: The Physiology of Provocation [1970] Crim. L.R. 634 at 636. It must be noted that Dr. Cannon's Original treatise (1915) was entitled Bodily Changes in Pain. Hunger, Fear and Rage.

13 "Psychobiology of Aggression and Violence" p. 79 Raven Press, New York (1981).

14 (1939) 5 W.A.C.A. 120.

15 This juju had a special name: "Onye $U k u$ "!

16 In the actual case, the deceased became very depressed because of the juju threat and committed suicide! $\mathrm{N}$. was charged under S. 310 of the Nigerian Code with "indirectly" causing her death. 
provocation not be available to him ${ }^{17}$ Should it make a difference that the emotion he experienced was fear and not anger? Should it make a difference that he felt both anger and fear? What if he goes to court and lies that he felt extremely angry ${ }^{18}$ as a result of the juju threat? Under our law, what the courts must do is to consider the provisions of Sections 318 and 283 in light of the circumstances giving rise to the provocation. As has been pointed out, the major hurdle here is whether "fear" can qualify as the sort of "passion" which can support a provocation defence. Other jurisdictions have recognized that fear is as proper a ground for reducing an of ence which would otherwise be murder to manslaughter as anger. ${ }^{19}$ Additionally, the requirement that the unlawful act $^{20}$ or insult must be such as would provoke an ordinary person of the same standing in life as the accused person will be tested by receiving evidence from persons with backgrounds similar to the accused person. In the Galikuwa ${ }^{21}$ case, the East African Court of Appeal accepted that under certain circumstances, the defence of provocation may be allowed in witchcraft cases. One of the conditions that the Court thought must be satisfied before the defence succeeds is that the facts of the case must establish that the deceased was performing some act in the presence of the accused which the latter believed, and which an ordinary member of his community would believe, was an act of witchcraft against him, and, additionally, the accused must have been so angered ${ }^{22}$ as to be deprived of his self-control. We see nothing objectionable about the above conditions which attempt to impose some limitations on the circumstances while accepting the principle that belief in the supernatural may be the basis of the plea of provocation. Indeed in an earlier case, the East African Court of Appeal had allowed the provocation defence where the provocation was caused by an overt act of witchcraft. ${ }^{23}$ The appellants who believed that the deceased, a witchdoctor, had caused the death of some relatives of theirs by witchcraft,

17 See the interesting case of A-G for Nyasaland v. Jackson [1962] R. \& N.L.R. 157. We must once again point out that where the dominant emotion is fear and not anger, the proper defence would seem to be self-defence; the point being made here ist that the courts must not refuse to consider the defence of provocation just because the accused acted out of fear and not anger. For one thing, the other ingredients which need to be present before self-defence may avail might be absent.

18 If a husband catches his wife committing adultery and kills her out of jealousy and not anger, is he to be denied the defence of provocation? Is the law not giving people an incentive to lie in such cases?

19 Illustrative is the following excerpt from the Wisconsin Judiciary Report on the Criminal Code (1953) "S. 340.03 Manslaughter. Whoever commits what would otherwise constitute first-degree murder . . under any of the following mitigating circumstances may be imprisoned for not more than 10 years.

(1) The crime is committed because the actor is under a mental disturbance caused by adequate provocation. Adequate provocation means provocation such as would be likely to cause a man ordinarily constituted to act instantly, rashly and without deliberation or reflection, from extreme rage or terror rather than from judgement ..." (quoted at p. 664 of Donnelly, Goldstein, Schwartz: Criminal Law (The Free Press (New York 1962). See also the Model Penal Code's definition of "manslaughter" in S. 210.3 (1980 ed.).

20 Chapter XX of the Nigerian Criminal Code, which is entitled "Ordeal, Witchcraft, Juju and Criminal Charms" declares unlawful certain trials by ordeal; S. 210 in particular creates certain specific offences in relation to witchcraft and juju.

21 Op. cit., note 65 .

22 We must once again deplore the limitation of the provocation defence to situations where it arouses anger.

23 R. v. Fabiano Kienene S/O Mukye (1941) 8 E.A.C.A. 96. 
found him one night crawling naked in the compound. They killed him in the ritualistic manner by stuffing green plantains up his anus. Their plea of provocation was accepted. Where the elements enumerated by Sections 318 and 283 are present, the Nigerian courts should not hesitate to accept the plea of provocation in these cases dealing with belief in the supernatural. Persons who kill while under genuine fear from threats from juju must not be given the death sentence. The influence of juju and the accompanying threats and fears that go with such influence is very real to many people living in towns and villages in Africa. Now that we have Nigerian judges sitting on the bench, a more sympathetic attitude should be adopted towards people who kill because that is the only perceived way out for them from the dilemma they find themselves in. ${ }^{24}$ Even when their pleas of provocation succeed, unlike cases in which self-defence is successfully pleaded, such defendants are not completely acquitted, they are still subject theoretically, to imprisonment for life. Should a person who kills another as a result of "juju threats" emanating from the victim be killed or be sent to prison? This is the dilemma that our judges must resolve in the "juju-provocation" cases.

\section{II}

We have to repeat that a very big gap exists between the rules of the criminal law and many social and cultural institutions that Nigerians treasure. This gap is particularly wide when we relate the criminal law to spouses as, compared to their counter-parts who contracted "Christian marriages ${ }^{25}$, those married according to customary law suffer acute discrimination from the criminal law. Whereas under the provisions of S. 33 of the Criminal Code, the wife of a Christian marriage is not criminally responsible for an act which she is compelled by her husband to do, and which act she does in his presence, ${ }^{26}$ such a defence is not available to a woman married under customary law. ${ }^{27}$ Unlike the husband and wife of a Christian marriage, customary law spouses can be charged and held criminally liable for conspiracy between the two of them alone. ${ }^{28}$ White under S. 36 of the Code, spouses of a Christian marriage acquire certain rights as well as immunities

24 Seidman (op. cit., note 60), noted that even in the cases where people who interpose beliefs in Supernatural phenomena as the basis of their provocation defence are convicted, "with monotonous regularity courts have ... in the same breath - recommended executive clemency". (at p. 46). For a typical case in which the accused is convicted, sentenced to death and a recommendation for executive clemency made see Kokomba, 14 W.A.C.A. 236.

25 S. 1 (1) of the Code defines "Christian marriage" as "a marriage which is recognised by the law of the place where it is contracted as the voluntary union for life of one man and one woman to the exclusion of all others".

26 If however, the act complained of constitutes an offence punishable with death or is an offence of which grievous harm to the person of another or an intention to cause such harm is an element, then even the woman married under Christian marriage will not escape liability.

27 The woman married under customary law, may however, benefit from S. 32 of the Code.

28 See S. 34 of the Criminal Code. 
in respect of dealings with each other's properties, this is not the case with customary law spouses. ${ }^{29}$

In the face of all this, one may be tempted to ask whether the long-established rule that a spouse may benefit from the defence of provocation where he or she catches the other in the act of adultery and retaliates by killing either the offending spouse or the lover, avails customary law spouses. Under the Customary Law in Nigeria, a man is allowed to marry as many wives as he wants. The argument may therefore be made that a woman who catches her customary law spouse "committing adultery" with another woman who is not one of his wives, cannot be provoked - the presumption being that, she must be "conditioned" to the fact that she does not have a monopoly of her husband in sexual matters. ${ }^{30}$ This kind of case has not as yet confronted the Nigerian courts, however, we can profit from examining some decisions handed down by some other jurisdictions. In Mwela Chinkupe, ${ }^{31}$ a case from the former Northern Rhodesia, the prisoner, a fish-seller of Lala tribe was charged with murder. He had overtaken the deceased while both were cycling, and without any preliminaries attacked and killed him with an axe and a knife. He pleaded provocation to the charge of murder on the ground that the deceased and the prisoner's wife had repeatedly committed adultery. Holding that he was guilty of murder, the court observed:

"It has been clearly laid down that the adultery must be of a lawful spouse, not merely intimacy, however reprehensible, with a fiancee or mistress. In the present case, the marriage of the prisoner was not a christian marriage and the status of his "wife " should not entitle him to take advantage of the law Referred to, even if he had discovered the parties in flagrante delicto. Which he did not. «32

Mwela Chinkupe can be explained on the basis of the racial factors that dominated Northern Rhodesian Society in those days. This highly illogical decision obviously takes a completely distorted view of human passions.

Let us compare this case with one from Kenya, Kalume wa Tuku alias Saidi v. R. ${ }^{33}$ The prisoner had been living with the deceased as man and wife for many years but had not lawfully married her. He returned home one day to discover her in bed with another man. He killed her in a rage. The trial judge held that provocation was not a tenable plea since the parties were not married. ${ }^{34}$ The East African Court of Appeal held that the

29 See also S. 10 of the Criminal Code - certain disabilities also exist under the Evidence Act for customary spouses which do not affect spouses under Christian marriage. See e.g. S. 160 (2) of the Evidence Act (1958).

30 See Savage v. McFoy (1909) 1 Renner Gold Coast Re. 504, where it was correctly held that a customary law marriage is a potentially polygamous marriage in which there can be no monopoly of the man.

31 (1953) 5 L.R.N.R. 276, the facts of this case are gleaned from Seidman: A Sourcebook of Criminal Law of Africa, (Sweet \& Maxwell, African University Press), 1966 ed.) at p. 212.

32 Emphasis supplied.

33 (1953) 21 E.A.C.A. 201.

34 The trial judge had indicated that he regarded the distinction between the law applicable to parties who are varried and parties who were not as "wholly artificial and unreasonable", and that he would have found the appellant guilty of manslaughter only if the law had permitted him. 
distinction based on lawful marriage did not apply in Kenya, and that "the mere fact that the parties were not married need not ... prevent the seducer or the woman from committing a 'wrongful act or insult' within the meaning of Section 204 of the Penal Code.

The decision of the Kalume Court is obviously preferable to that handed down by the judges in Mwela Chinkupe. Nigerian Courts, it is submitted, would not endorse the principle adumbrated by the Northern Rhodesian Court as far as it relates to the availability of the defence of provocation to a man married under customary law. ${ }^{35}$ Indeed, the main stumbling block in the path of a woman married under customary law is not that her customary law marriage is unlawful, but rather the difficulty of satisfying the objective test of provocation. To put it bluntly, a woman married under customary law to a man who has other wives knows that her husband sleeps with those other women. Is she therefore assumed to accept the fact that her husband can sleep with just any woman whether he is married to her or not? Should the defence of provocation be forceclosed to a woman who is engaged in an active polygamous marriage even where her husband sleeps with women he is not married to? This question cannot and must not be answered in the abstract. When an actual case comes up before the Nigerian courts, they must examine the circumstances giving rise to the plea against the provisions of Section 318 and 283 of the Code to determine if the defence should avail. ${ }^{36}$

We must also point out that the common law for no sound reasons limits the defence of provocation to spouses only. The defence is not available to engaged couples, neither can a man who has been cohabiting with a mistress for many years raise the defence if he comes home one day and catches her in the act of adultery with another man in his own bed. In R. v. Mawgridge $e^{37}$ it was said that adultery is the "highest invasion of the man's property", and that in the unmarried situation, the man "has no such control" over his inconstant lover. There are situations in which the passions of a man who is engaged to a young lady to be married would be more violently aroused when he catches his fiancee in

35 In fact, many cases have come before the Nigerian courts involving husbands of customary law marriages who killed either one of their many wives or the single wife they may have due to provocation. The courts have gone ahead and considered the doctrine of provocation in relation to the factual situation before them without attempting to limit the defence on grounds of polygamy. See, for e.g., Adekanmi, (1944) 17 N. L. 99, John v. Zaria N. A. (1959) N.R.N.L.R. 43, See also the Ghanaian case of Simbore Grunshie v. R. Jan-June (1960) Cyclostyled Judgements of the Supreme Court of Ghana, 2.

36 Let us consider one or two hypothetical cases. Kayode, a businessman from Lagos has been paying court to Sumbo, a final year student from the University of Ife, with a view to marrying her. Sumbo stoutly fences off his advances, because Kayode is already married. Kayode promises her that if she agreed to be his second wife he will never marry again and neither will be have affairs with any more women. Sumbo agrees and becomes his second wife. She comes home one afternoon from work and catches Kayode in bed with another student from the University of Ife. Surely if she kills Kayode in the heat of passion caused by sudden provocation before her passion could cool down, she should benefit from the defence of provocation. Again, if Sumbo came back home one day and found Kayode seducing her younger sister who had come to stay with them during the long vacations, the defence of provocation should not be denied her on the ground only that she has contracted a polygamous marriage.

3784 Eng. Rep. 1107 at 1115. 
the act of adultery than would be the case with two people who are actually married. As Dr. Aguda ${ }^{38}$ has pointed out, "a young man who is devoted to his fiancee whom he is about to marry may suffer more injury and be far more provoked if he discovers his loved one in the course of illicit sexual intimacy with another man than a man who has for years been wishing for a divorce from a much-hated wife would be if he discovers her committing adultery with another man. ${ }^{39}$

There is nothing in the rules relating to provocation under the Criminal Code of Nigeria that limits the defence of provocation to lawfully married couples, while excluding lovers or engaged couples. As the East African Court of Appeal pointed out in relation to identical provisions of the Kenya Penal Code, "the mere fact that the parties were not married need not, ... prevent the seducer or the woman from committing a wrongful act or insult ..." within Section 283 of our Criminal Code. It is submitted that in the proper circumstances, the defence of provocation under Sections 283 and 318 should be available to paramours, engaged couples and people living together as husband and wife without actually having gone through a formal marriage ceremony. The old common law rules which limited the provocation defence to lawfully married spouses ${ }^{40}$ probably made sense when viewed against the background of the moral as well as socio-cultural values of Englishmen of those days; today, the rule is simply unrealistic, illogical and totally unpalatable.

III

Another provision which might militate against the survival of the provocation defence is that the provocation must, among other rhings, be "sudden". The requirement of suddenness is said to ensure that the actor kills while he is caught in the throes of passion and not out of revenge. The psychological assumption behind this requirement is that where the things said or done to the accused are sudden or unexpected, the accused is apt to be more provoked. Explaining the law of provocation to the jury in Duffy, ${ }^{41}$ Devlin $\mathrm{J}$. directed them as to the requirement of suddenness in these words:

"Severe nervous exasperation or a long course of conduct-causing suffering and anxiety are not by themselves sufficient to constitute provocation in law. Indeed, the further removed an incident is from the crime, the less it counts. A long course of cruel conduct

38 "Principles of Criminal Liability in Nigerian Law (Univ. of Ibadan Press 1965), p. 312.

39 Sec, for e.g., the case of Kennedy [1951] (4) S.A. 431 where the appellant killed his ex-wife whohad promised to remarry him, on the eve of the date for the second marriage when he caught her in an intimate position with another man. The defence of provocation was denied him.

40 See, for example, the old cases of R. v. Palmer [1913] 2 K. B. 29 and R. v. Greening [1913] 3 K. B. 846 where the defence of provocation was denied to spouses who had - either been living together or were engaged to be married.

41 [1949] 1 All E.R. 932. 
may be more blameworthy than a sudden act provoking retaliation, but you are not concerned with blame here ... (42 $^{42}$

Obviously, if A kills B, and his defence is that B provoked him yesterday at a party, he is liable to be convicted of murder because the suddenness requirement is not satisfied. However, it is not always possible to judge the gravity of provocation by merely focussing on the single conduct that preceded the retaliation from the prisoner. As was pointed out by Jackson J. in Mehetmet Ali v. R., ${ }^{43}$ "The final wrongful act or insult might, of itself, be comparatively triffling, but when taken with what had gone before, might be taken as the last straw in a cummulative series of incidents which finally broke down the accused's self-control and caused him to act in the heat of passion. " ${ }^{44}$

The above observations of the court in Mehetmet Ali, have certain important implications for the provocation doctrine. Here again conflicting policy considerations clash headlong. How far should the "suddenness" requirement be carried? In cases where there has been a long course of provocation served by the victim to the accused, common sense would seem to mandate that the rigid application of the "suddenness of provocation" requirement is relaxed..$^{45}$

Let us examine the Ghanaian case of Simbore Grunshie ${ }^{46}$ from the perspective of cummulative provocation. ${ }^{48}$ Appellant had two wives. Kofi, a Tigare priest came to visit him, and as he had only one room, the visitor slept in the same room with him and his two wives for the month that he stayed with him. The appellant went to work each day, leaving his wives and the visitor behind. He returned one day to discover that Kofi had enticed both wives away. He managed to recover his wives and they lived together peacefully for three weeks. One day he returned to his house and heard Kofi trying to entice the women away again. He charged into the house but the priest escaped over a wall. Thereupon one of his two wives began to abuse him, calling him "hopeless man", a "foolish man" and told him that whether he liked it or not she was going to marry the Tigare priest. He seized a cutlass and killed both his wives. Is it not possible that in this case, the final series of events, i. e. (a) hearing Kofi planning to entice away his wives again, (b) one of them insulting him and (c) declaring contemptously that she was going to marry Kofi whether the accused liked it or not, when superimposed on the fact that the same Kofi had previously enticed away his wives might constitute sufficient provocation?

Be that as it may, the requirement that the provocation must be sudden will prove a formidable obstacle to cases of domestic killings as a result of cumulative provocation.

42 Ibid at p. 933 (Emphasis added).

43 [1957] W.A.L.R. 28.

44 Ibid, at p. 39. See also Thuku (alias Nyaga) v. Republic [1965] E.A. 496 (Emphasis added).

45 Another possible obstacle to allowing the defence in cases of cumulative provocation is that the killing was not done "in the heat of passion".

46 Op. cit., note 35.

47 Although the defence relied on provocation, the issue of cumulativeness was not considered. The case was argued and decided on the issue whether suspicion of adultery could constitute sufficient provocation. 
The reported cases show that most provocation killings in Nigeria involve relatives, ${ }^{48}$ friends, lovers or people generally living in the same household. And the factor that makes this situation even more dangerous is the fact that such people have constant inter-action with each other. As the facts of Thuku (alias $N y$ aga) v. Republic ${ }^{49}$ will show, provocation in such cases may involve a programme of insulting or cruel conduct by the deceased in a domestic setting which eventually results in either the party who is at the receiving end of the provocative conduct or a third party acting on his or her behalf killing the rogue. In $T h u k u,{ }^{50}$ appellant came home one night and found his stepfather beating his mother. When he tried to stop the beating his stepfather hit him twice on the head with a stick warning him not to interfere in a fight between husband and wife. The appellant then went to sleep indoors only to wake up a few hours later in response to a call from his stepfather. He went outside and found his mother dead from a severe head injury. He took a panga from the house and chased his stepfather to a house some three hundred yards away. They then exchanged words which further infuriated the appellant and while they were walking back towards the corpse of his mother, he killed his stepfather. The trial judge having rejected his plea of provocation to a charge of murder on the ground that enough time had elapsed for passion to cool, Thuku appealed to the Court of Appeal for Eastern Africa. The Court upheld the appeal on the ground that the incidents formed a connected series of events which made the actual killing of his mother so proximate to him as to have been constructively done in his presence and that, taking into consideration the degree of provocation, enough time had not elapsed for passion to cool.

Wife-beating or general ill-treatment of wives as well as stepchildren ${ }^{51}$ is very common in homes in Nigeria - and other parts of Africa as well. ${ }^{52}$ Incidents of wifebeating are not confined to the so-called "primitive illiterate peasants"; sometimes, persons who hold doctoral degrees in various academic fields subject their wives to constant doses of physical abuse. Can a woman who has been the victim of such cruelty and violence rely on the whole course of provocative events if one day she retaliates and kills her husband? The obstacles which are likely to stand in the way of the provocation plea in such circumstances are rather formidable. More often than not in such cases, there is no apparent final event that precipitates the provocation, or the final provoking event may, if viewed in isolation, appear trivial. We may also point out that some courts view a

48 The killing of Abel by Cain (Genesis 4:1-8) which is the first reported crime in the world, involved a domestic killing. Although jealousy was the major reason there is no doubt that it sprang from a series of preferential acts shown to Abel.

49 [1965] E. A. 496.

50 Ibid.

51 Step-Children, like Cinderella in the fairy tale, of ten suffer untold cruelty from foster-parents. This situation is made worse by the fact that because corporal punishment of wards and children is socially accepted in Nigeria, it is very difficult to distinguish the legitimate exercise of the right of "corrective punishment " from child-abuse or cruelty simpliciter.

52 The incidence of wife-beating and abuse is particularly common in homes where the husband is a heavy and habitual drinker. 
killing which follows a course of cumulative provocation as less deserving of legal sympathy than killings which result from immediate retaliation to stress or provocation. "The argument here is that someone who is continually provoked. Over a period of time has ample opportunity to come to terms with his plight - and therefore ought to do so. " ${ }^{53}$ Additionally, as we have pointed out, killings which follow a long diet of cumulative provocation are liable not to satisfy the legal requirement that the actor must act "in the heat of passion caused by suden provocation".

The plain truth of the matter is that killings which follow a long course of provocation deserve mitigation as much as those which follow immediately as sudden reactions to stress or provocation. We fully endorse Professor Ashworth's sentiment that "the proposition that those who repress their anger until it finally explodes are less deserving of mitigation than those who react immediately to stress or provocation is neither intuitively appealing nor founded on scientific distinction. ${ }^{54}$ Glanville Williams's highly persuasive opinion is that "Where provocation has been given and cooling time has elapsed, smaller incidents may reopen the provocation than would be sufficient to constitute provocation if there had been no previous incident. The old provocation, like an old wound, may be reopened by a new affront, which need not in itself be sufficient to constitute provocation, and a person who kills when smarting under the fresh attack will be judged on the whole background of his act." ${ }^{55}$

A housewife who has been at the receiving end of provocation throughout her married life may have not be in a position to exercise her one obvious option - i. e. pack her things and go. For one thing she may still love her husband despite his cruelty. Secondly, she may fear the humiliation and degradation which normally go with divorce or separation, more than the physical abuses she has been receiving. There is also the fear that without a husband to support her, especially where she has many children from the marriage, she will be worse off. Of course, there is also the possibility that if she reports her husband to relatives, not only will she suffer acute embarrassment which the revelation of the intimate details of her married life will entail, but also that she might receive worse beatings.

In our view, killings which result from cumulative provocation should not be disqualified from benefitting from the provocation defence just because the provocation was not "sudden". In every case, the fact-finder should be directed to find whether there are mitigating circumstances which surround the killing or whether the actor finally killed his tormentor out of revenge. No one can tell accurately how the ordinary person in Nigeria feels about killings which follow upon cumulative provocations, however, as has been reported in relation to the same issue in England, "juries appear to believe that cumulative provocation raises stronger, rather than weaker grounds for mitigation " .56

53 Ashworth "Sentencing in Provocation Cases" [1975] Crim. L.R. 553 at 558.

54 Ibid.

55 Op. cit., note 3, p. 529.

56 Ashworth: op. cit. at 558. 
It needs repeating that the penalty for murder in Nigeria is still death. There are thousands of housewives in Nigeria today who suffer untold cruelty as well as violence from husbands whose constant companion is drink. Is it asking too much that before we decide to hang a housewife who kills her husband one evening after what might objectively appear to be trifling provocation, the courts admit evidence of the whole course of provocative conduct that finally reached a flashpoint so as to be in a better position to decide whether "an ordinary person" of similar standing in life would have reacted similarly or not? Of course, where evidence exists to the effect that the final killing was carefully planned and executed, then she cannot benefit from the provocation defence. A case illustrating this last point is from the former Rhodesia. ${ }^{57}$ The accused killed her husband by poisoning his beer. Throughout their married life of nine years he had constantly abused her. She obtained some arsenic of soda a month earlier, with a view to poisoning him. On the day in question, her husband again beat her up severely with the handle of a hoe at 2 p.m. She put the poison in her husband's beer at 6 p.m. and left to join a dance. She returned at dawn to find out that someone else had consumed the beer meant for her husband. Her husband then returned and abused her again. She thereupon put more poison in another vessel of beer which her husband drank and from which he died. The Court held, inter alia, that the act of obtaining the poison in advance demonstrates premedidation. The non-availability of the defence of provocation in cases where the party actually premeditates the killing is based on the sanctity of human life - even if the human being in question happens to be the lowest of the species. A judgement is apparently being made that where the tormented party reaches a point where he or she decides to kill out of revenge, then the time has truly come to pack up and go. Legal provocation and premeditation, as Dr. Glanville Williams has pointed out, are incompatible concepts.

\section{Conclusion}

This paper has attempted to foreshadow and provide answers to some hard issues that are likely to confront our courts when the defence of provocation is raised. We have tried to show that the Code provisions do not necessarily debar accused persons from raising the provocation defence simply because they acted out of fear of the supernatural. We have also argued that customary law spouses, engaged couples as well as persons who react to cumulative provocation are not by reason of their status only or the nature of their particular cases foreclosed from using the provocation defence. The overriding common denominator that the courts should apply in all provocation is whether the actor killed in the heat of passion caused by provocation before there is time for passion to cool. It is submitted that this is the only interpretation which ensures the survival of the provocation defence in Nigeria. 
tion agreements with the EEC in January 1976. The leaders of the Maghreb states thoroughly recognize that Maghreb unity meets the modern demands for regional association in order to foster economic development.

\section{Additional Posers in the Provocation Law of Nigeria}

\section{By G. N. Vukor-Quarshie}

In many former colonies the law has remained strongly informed by the legal tradition and colonial legislation of the erstwhile imperial power. After independence the problem of reconciling such imposed legislation or doctrine with native customs, values and beliefs appeared in even sharper focus than under colonial rule, the newly independent state having become the master of its own municipal legal order.

The English-law doctrine of provocation affords a plea to reduce the criminal responsibility of a party who, incited by such provocation, committed a criminal offence. This rule often proved difficult of application in colonial societies where, e.g., the institutions of customary law marriage presented circumstances different from those prevalent in England, thereby complicating recourse to the concept as applied to spouses in England. There also exist in colonial societies practices, such as witchcraft, which in view of the widespread belief in their efficacy could welldramatically affect a person on whom such magical art was exercised. The law of the colonial power, however, refused to take account of such superstition in determining whether a plea of provocation should be allowed.

The article describes specific problem areas in the law of provocation where the colonial judiciary failed to take adequately into account the peculiarities of the native society and identifies related questions which even after independence remain to be resolved in modern Nigerian criminal law.

\section{'Law' and 'Custom` in Papua New Guinea: Separation, Unification or Co-operation?}

\section{By Peter G. Sack}

It begins with a characterisation of the two spheres approach adopted by the colonial powers which separated 'law' and 'the stater on one hand from 'custom' and 'society' on the other, combining a limited de facto recognition of 'custom ' by the colonial state with an even more selective, official recognition of 'custom ' in its courts, using a quasi-private-international-law model for the purpose. 